\title{
A cell junction pathology of neural stem cells leads to abnormal neurogenesis and hydrocephalus*
}

\author{
Esteban M. Rodríguez ${ }^{1}$, María M. Guerra ${ }^{1}$, Karin Vío ${ }^{1}$, César González ${ }^{1}$, Alexander Ortloff ${ }^{1}$, Luis F. Bátiz ${ }^{1}$, Sara \\ Rodríguez ${ }^{1}$, María C. Jara ${ }^{1}$, Rosa I. Muñoz ${ }^{1}$, Eduardo Ortega ${ }^{2}$, Jaime Jaque ${ }^{2}$, Francisco Guerra ${ }^{3}$, Deborah A. Sival ${ }^{4}$, \\ Wilfred F. A. den Dunnen ${ }^{4}$, Antonio J. Jiménez ${ }^{5}$, María D. Domínguez-Pinos ${ }^{5}$, José M. Pérez-Fígares ${ }^{5}$, James P. \\ McAllister ${ }^{6}$, Conrad Johanson ${ }^{7}$
}

\author{
1 Instituto de Anatomía, Histología y Patología, Universidad Austral de Chile, Valdivia, Chile. \\ 2 Instituto de Neurociencias Clínicas, Universidad Austral de Chile, Valdivia, Chile. \\ ${ }^{3}$ Instituto de Obstetricia y Ginecología, Universidad Austral de Chile, Valdivia, Chile. \\ ${ }^{4}$ Departments of Pediatric Neurology y Pediatrics, University Medical Center. University of Groningen, The Netherlands. \\ ${ }^{5}$ Departamento de Biología Celular, Genética y Fisiología, Facultad de Ciencias, Universidad de Málaga, Spain \\ ${ }^{6}$ Department of Neurosurgery, Pediatric Neurosurgery Division, University of Utah, UT, USA. \\ 7 Department of Neurosurgery, Alpert Medical School at Brown University, NY, USA.
}

\begin{abstract}
Most cells of the developing mammalian brain derive from the ventricular (VZ) and the subventricular (SVZ) zones. The VZ is formed by the multipotent radial glia/neural stem cells (NSCs) while the SVZ harbors the rapidly proliferative neural precursor cells (NPCs). Evidence from human and animal models indicates that the common history of hydrocephalus and brain maldevelopment starts early in embryonic life with disruption of the VZ and SVZ. We propose that a "cell junction pathology" involving adherent and gap junctions is a final common outcome of a wide range of gene mutations resulting in proteins abnormally expressed by the VZ cells undergoing disruption. Disruption of the VZ during fetal development implies the loss of NSCs whereas VZ disruption during the perinatal period implies the loss of ependyma. The process of disruption occurs in specific regions of the ventricular system and at specific stages of brain development. This explains why only certain brain structures have an abnormal development, which in turn results in a specific neurological impairment of the newborn. Disruption of the VZ of the Sylvian aqueduct (SA) leads to aqueductal stenosis and hydrocephalus, while disruption of the VZ of telencephalon impairs neurogenesis. We are currently investigating whether grafting of NSCs/neurospheres from normal rats into the CSF of hydrocephalic mutants helps to diminish / repair the outcomes of VZ disruption.
\end{abstract}

Key words: hydrocephalus, abnormal neurogenesis, neural stem cells, stem cell transplantation

\section{INTRODUCTION}

It is now understood that hydrocephalus is not only a disorder of CSF dynamics, but also a brain disorder, and that derivative surgery does not resolve most aspects of the disease (Jones and Klinge, 2008). Indeed, $80-90 \%$ of the neurological impairment of neonates with fetal onset hydrocephalus is not reversed by derivative surgery. How can we explain the inborn and, so far, irreparable neurological impairment of children born with hydrocephalus? In 2001, Miyan and his co-workers asked a key question: "Humanity lost: the cost of cortical maldevelopment in hydrocephalus. Is there light ahead?" We think that there is some light. There is evidence that the common history of congenital hydrocephalus and brain maldevelopment starts early in the embryonic life with the disruption of the ventricular (VZ) and subventricular (SVZ) zones. However, the nature, mechanisms and extent of the brain impairment linked to hydrocephalus are far from been fully unfolded. We agree with Del Bigio (2001) and Williams et al., (2007) that better treatment of hydrocephalus and the associated neurological impairment will come from a better understanding of the biological basis of the brain abnormalities in hydrocephalus. We think that this view may represent one of the 'lost highways' in hydrocephalus research, as described by Jones and Klinge (2008).

Virtually all cells of the developing mammalian brain are produced in two germinal zones that form the ventricular walls, the VZ and the SVZ (Fig. 1A) (Jacobsen, 1991; Brazel et al., 2003; Gotz and Huttner, 2005; Merkle and Alvarez-Buylla 2006; Malatesta et al., 2008). The VZ is a pseudostratified neuroepithelium that contains multipotent radial glia/ stem cells, hereafter called neural stem cells (NSCs). NSCs line the ventricular lumen and through a long basal process reach the pial surface. A landmark of NSCs is their primary cilia that project to the ventricle and are bathed by the fetal cerebrospinal fluid (CSF, Fig. 1E) (Mori et al., 2005; Kazanis et al., 2008). During a fixed period of brain development, NSCs divide asymmetrically, with one daughter cell remaining as a NSC and the other becoming a neural progenitor cell (NPC). Late in development a population of NSCs differentiates into immature ependyma, which during the first postnatal week mature into ependyma (mouse) (Fig. 1A). In the human, ependymal cell differentiation starts at about the fourth week of gestation and is completed around the 22nd gestational week (Sarnat, 1992). The SVZ is located underneath the VZ along the lateral walls of the lateral ventricles of the embryonic

\footnotetext{
* Dedicated to Fondecyt for 30 years of support.
}

Corresponding author: Esteban M. Rodríguez MD, PhD, Instituto de Anatomía, Histología y Patología Facultad de Medicina, Universidad Austral de Chile, Valdivia, Chile. E-mail: erodrigu@uach.cl. Phone: +56 63221206 - Fax: +56 63221604 
brain; it contains the neural precursors, which lose contact with the ventricular surface, proliferate extensively and then differentiate into migratory neuroblasts (Fig. 1A) (Brazel et al., 2003; Bonfanti and Peretto, 2007).

Over the years, based on our own and other investigators' evidence, we have progressively come to the view that a disruption of the $V Z$ and $S V Z$, in most cases due to genetic defects, triggers onset of congenital hydrocephalus and abnormal neurogenesis (Fig. 1B). We discuss this evidence in the present review.

\section{CELLULAR AND MOLECULAR MECHANISMS OF VENTRICU- LAR ZONE DISRUPTION}

For clarification purposes we shall define the terms used in the present paper to refer to the VZ. At stages of development when the VZ is mostly formed by radial glia/NSCs, the acronym "VZ" will be used. When the VZ is mostly or exclusively formed by multiciliated ependymal cells, the term "ependyma" will be used. The terms "denudation", "disruption" or "loss" will be alternatively used to refer to the disassembling, disorganization, or loss of the VZ cells.

The disruption of the VZ follows a program that has temporal and spatial patterns, progressing as a "tsunami" wave running from the caudal to rostral regions of the developing ventricular system, leaving behind a severe damage. Radial glial/neural stem cells, immature ependyma and mature ependyma all have distinct phenotypes and certainly play quite different roles (Kazanis et al., 2008). What do they have in common so that the denudation wave will hit them all? Junctional proteins appear to be the key to understanding this devastating phenomenon. Up to embryonic day 12 (E12), neuroepithelial cells lining the neural tube are joined together by gap, adherens and tight junctions (Fig. 1A) (Mori et al., 2005; Kazanis et al., 2008). From E12 onward, tight junctions are missing and cell-to-cell adhesion relies on gap and adherens junctions. It is exactly at this time, E12, when disruption of the VZ starts in the mutant hyh mouse (Jiménez et al., 2001) (Fig. 1A). What do all the different mutant mouse strains undergoing VZ denudation have in common? Overall, a series of findings indicates that disruption of the $\mathrm{VZ}$ arises from a final common pathway involving alterations of vesicle trafficking, abnormal cell junctions and loss of VZ integrity (Ferland et al., 2009).

Cadherins play a key role during neural tube formation (Ivanov et al., 2001) and represent the major calciumdependent cell junction molecule in the $\mathrm{VZ}$ and later in the ependyma (Fig. 1A, 2A-E) (Hatta et al., 1987; Chenn et al., 1998). Antibodies against chicken $\mathrm{N}$-cadherin injected into the fetal CSF disrupt the VZ and lead to denudation of the SVZ and formation of periventricular rosettes (Ganzler-Odenthal et al., 1998). In the hyh mouse the mutated gene encodes for $\alpha$ Snap (Chae et al., 2004), a key protein in intracellular trafficking. This mutation results in abnormal transport of $\mathrm{N}$-cadherin to the plasma membrane of NSCs (Chae et al., 2004). As discussed below, these mice undergo a massive disruption of the VZ. Disruption of the VZ occurs in mice in which adherens junction formation has been impaired by removal of regulatory molecules such as Lgl1 (Klezovitch et al., 2004), atypical protein kinase C-lambda (aPKC $\lambda$ ) (Imai et al., 2006), and non-muscle myosin II-B (NMII-b) (Ma et al., 2007). Various other animal models with a defect in cell-cell junctions undergo VZ disruption, abnormal translocation of cells into the ventricle and hydrocephalus (Kamiguchi et al., 1998; Tullio et al., 2001; Bátiz et al., 2009).

Gap junctions are now regarded not only as channels between neighboring cells, but also as signaling complexes that regulate cell function (Saez et al., 2003; Dbouk et al., 2009). Connexins also form functional hemichannels that provide a pathway linking the intra and extra-cellular milieu (Saez et al., 2005; Dbouk et al., 2009; Orellana et al., 2009). Gap junctions play an important role in cell-cell coupling to maintain synchronized ependymal ciliary beating (Goodenough et al., 1996; Perez Velazquez et al., 2000; Rouach et al., 2002) and CSF flow (Banizs et al., 2005). A series of studies indicates that the formation of gap and adherens junctions are interrelated phenomena (Jongen et al., 1991; Meyer et al., 1992; Fujimoto et al., 1997; Wei et al., 2005; Oka et al., 2006; Laird 2006; Derangeon et el., 2009). This may explain how in the SA of Spina Bifida Aperta (SBA) patients the same VZ cells display abnormalities in both $\mathrm{N}$-cadherin and connexin 43 (Fig. 2E-H) (Sival et al., 2011).

Recently we have demonstrated that the VZ/ependymal cells of human fetuses are joined together by N-cadherin-based adherens junctions and gap junctions (Guerra et al., 2010; Sival et al., 2011). In SBA patients, areas of SA about to become denuded display disorganized VZ/ependyma cells with an abnormal subcellular location of $\mathrm{N}$-cadherin and connexin 43 (Fig. 2D-H). This mirrors what is seen in animal models with a defect in cell-cell junctions. The increased amount of both junction proteins in the cytoplasm of the abnormal $\mathrm{VZ}$ cells might reflect abnormalities in their transport to the plasma membrane or, less likely, in their internalization and degradation (see Laird 2006).

In brief, abnormal cell junctions of the VZ cells appear as a final common pathway in the alteration of a series of molecules directly or indirectly involved in the assembly of adherens and gap junctions (Chae et al., 2004; Ferland et al., 2009; Sival et al., 2010; Bátiz et al., 2006; Klezovitch et al., 2004; Imai et al., 2006; Ma et al., 2007; Rasin et al., 2007; Nechiporuk et al., 2007). This may explain how a series of different genetic defects affecting the VZ/ependyma finally leads to its disruption, hydrocephalus and abnormal neurogenesis.

A recent finding has shown that non-genetic mechanisms can also lead to VZ disruption (Fig. 1B). Lysophosphatidic acid, a blood-borne factor found in intracranial haemorrhages, binds to receptors expressed by the VZ cells and triggers VZ disruption and hydrocephalus (Yung et al., 2011).

\section{DISRUPTION OF THE VENTRICULAR ZONE OF THE SYLVIAN AQUEDUCT LEADS TO HYDROCEPHALUS}

We have extensively studied the mutant mouse hyh (hydrocephalus with hop gait) that develops fetal onset hydrocephalus. This mutant displays certain characteristics that make it an appropriate animal model of congenital hydrocephalus. Phenotypical characteristics, such as time of onset, type of abnormal CSF dynamics, clinical evolution, and survival/death rate (Jiménez et al., 2001; Wagner et al., 2003; Bátiz et al., 2005; Páez et al., 2007), are similar to those found in several types of human congenital hydrocephalus.

In the hyh mouse, a programmed disruption of the $\mathrm{VZ}$ of the ventral wall of the aqueduct (SA) starts early in fetal life (E12.5) (Fig. 1A) and precedes the onset of a moderate 

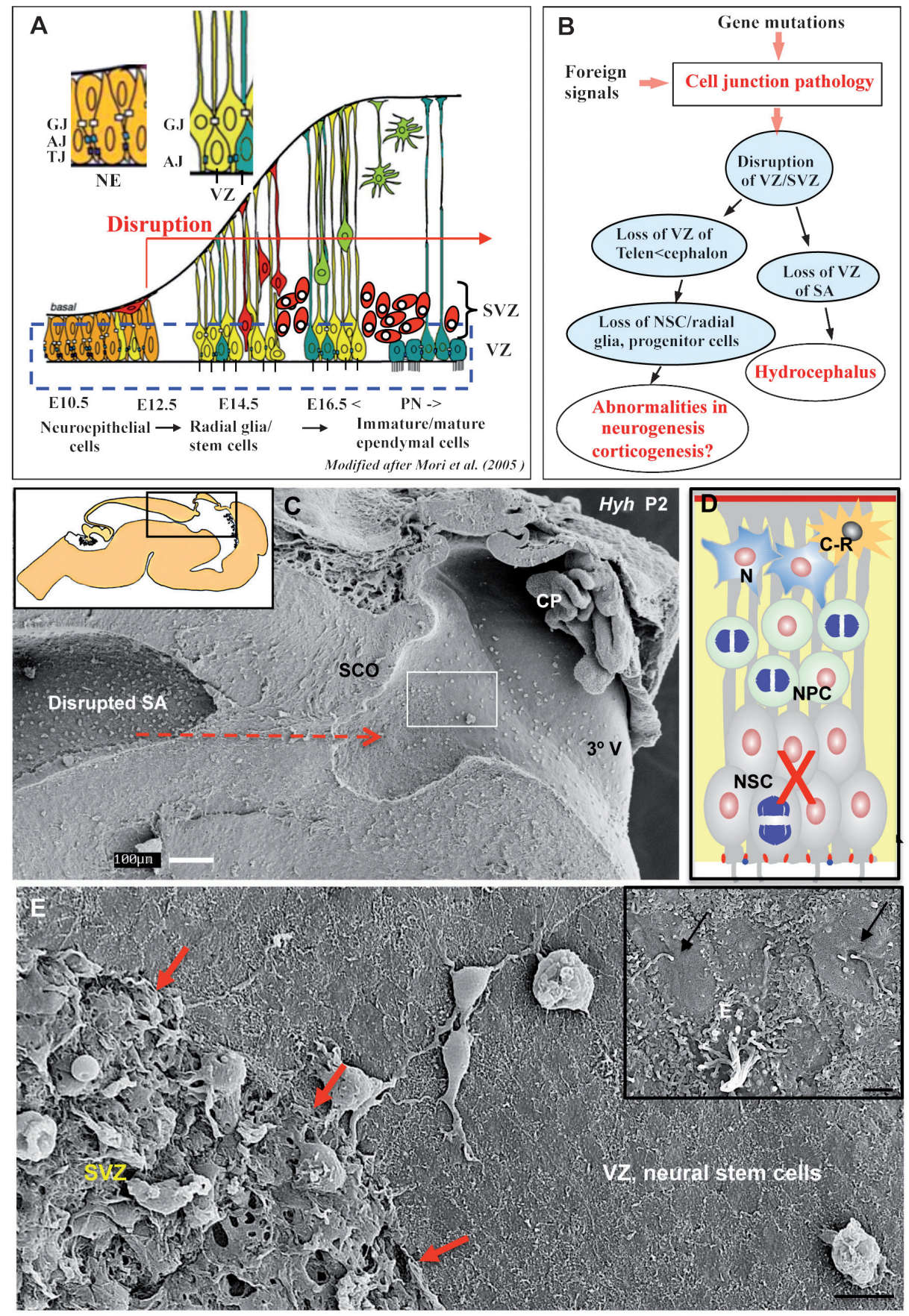

Figure 1. Ventricular zone development and its disruption in hydrocephalic mutant mice. A, Drawing depicting development of the mouse neural tube. Up to E12, the tube is lined by neuroepithelial cells (orange) joined together by gap (GJ), adherens (AJ) and tight (TJ) junctions. After E12, neuroepithelial cells start to differentiate into radial glial/stem cells (yellow). These cells form the ventricular zone (VZ), lining the lumen of the neural tube. At about E14, the stem cells begin to divide asymmetrically, with one of the daughter cells becoming neural precursor cells (red) that form the subventricular zone (SVZ). Late in embryonic life and early in postnatal life, radial glia/stem cells differentiate into ependymal cells that line the ventricular walls of the adult brain. In the mutant mouse hyh, disruption of the ventricular zone starts at E12. B, Flow chart representing the hypothesis that cell junction pathology of the VZ cells leads to both hydrocephalus and abnormal neurogenesis. C, Scanning electron microscopy of a newborn hyh hydrocephalic mutant mouse. Disruption of ventricular zone along the Sylvian aqueduct and ventricle progresses as a wave expanding caudal-rostrally (broken red arrow). The rectangle frames the disruption front shown in E. Inset: Drawing of the hyh mouse brain. The area framed is similar to that shown in $\mathrm{C}$. $\mathrm{CP}$, choroid plexus; $3^{\circ} \mathrm{V}$, third ventricle; SCO, subcommissural organ. D, Drawing of the cells forming the ventricular zone (NSC, neural stem cells) and the subventricular zones (NPC, neural precursor cells) of the developing mouse brain. N, Neuron; C-R, Cajal Retzius cell. Disruption of the VZ (large red X) implies the loss of NSC. E, Detailed view of area framed in figure C. Red arrows point to the disruption front, leaving behind the denuded subventricular zone (SVZ). Inset: High magnification of two stem cells (arrows) displaying a primary cilium and one multiciliated ependymal cell (E). Bars: C, $100 \mu \mathrm{m} ; \mathrm{E}, 6 \mu \mathrm{m}$; inset in $\mathrm{E}, 1 \mu \mathrm{m}$.

Figs. C and E: from Wagner et al. 2003 

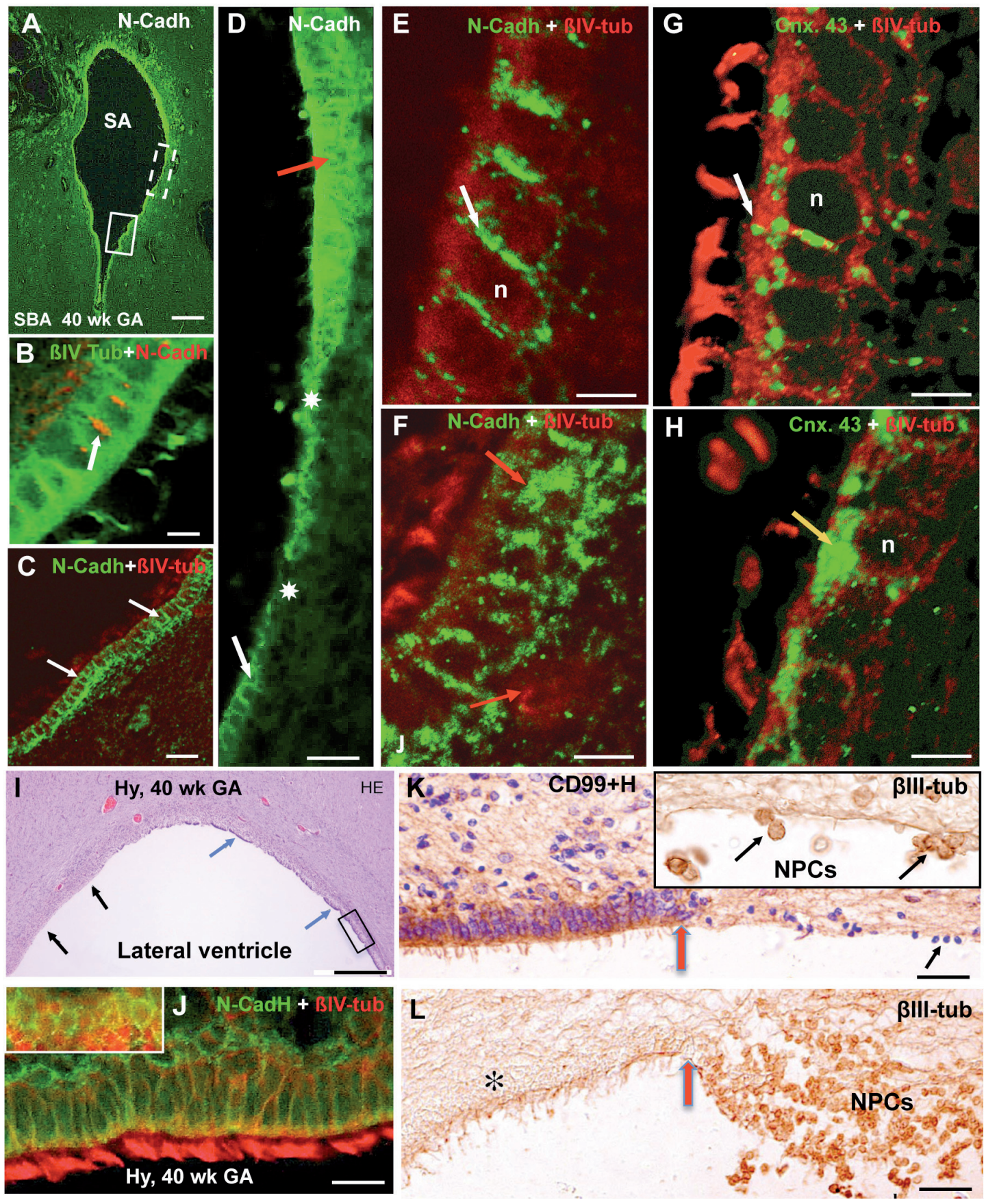

Figure 2. The ventricular zone of the Sylvian aqueduct and telencephalon of human hydrocephalic fetuses undergo disruption. A-H, Cross section of the Sylvian aqueduct of a fetus with spina bifida aperta (SBA), 40 week gestational age. A, Immunofluorescence for $\mathrm{N}$-cadherin. In the wall of the SA, regions with a normal appearance (solid line rectangle) coexist with others undergoing disruption (broken line rectangle). B, C, Detailed magnification of area shown in solid line rectangle of Fig. A. Normal expression of $\mathrm{N}$-cadherin in ependymal cells not yet affected. The protein is mostly located at the lateral plasma membrane, forming adherens junctions (arrows). D, Micrograph of area similar to that framed by the broken line rectangle in Figure A. There are areas with normal location of $\mathrm{N}$-cadherin (full white arrow), others with little or no N-cadherin (asterisk) and still with cells loaded with this protein (red arrow). E, F, Confocal microscopy of ependyma with normal ( $E$, white arrow) and abnormal ( $F$, red arrow) expression of $N$-cadherin. $n$, cell nucleus. G, $\mathbf{H}$, Confocal microscopy of ependyma with normal ( $E$, white arrow) and abnormal ( $F$, orange arrow) expression of connexin 43. $n$, cell nucleus. I-L, Telencephalon of a hydrocephalic human fetus, 40 weeks gestational age. I, In the lateral ventricle there are large areas devoid of ependyma (black arrows) and others lined by ependyma (blue arrows). J, Area of normal ependyma similar to that framed in Fig. I, double immunostained for N-cadherin (green) and bIV-tubulin (red). N-cadherin is arranged in the lateral plasma membrane as a complete belt (see insert). K, Border region between normal and denuded ependyma (red arrow). Immunostaining with anti-CD99. In the denuded area, $\beta$ III-tubulin+ neural precursors (NPCs) (see insert) reach the ventricular lumen. L, A large mass of $\beta I I I-t u b u l i n+$ neural precursor cells (NPCs) are translocated to the ventricle. Arrow, border between intact (asterisk) and disrupted ependyma. Bars: A, $350 \mu$; $\mathrm{B}, 9 \mu \mathrm{m} ; \mathrm{C}, 36 \mu \mathrm{m}$; D, $21 \mu \mathrm{m} ; \mathrm{E}-\mathrm{F}, 7 \mu \mathrm{m} ; \mathrm{G}, 8 \mu \mathrm{m}$; H, $5 \mu \mathrm{m}$; I, $250 \mu \mathrm{m}$; J, $11 \mu \mathrm{m} ; \mathrm{K}-\mathrm{L}, 25 \mu \mathrm{m}$.

Figs. A-H: from Sival et al. 2011. Figs. I, K, L: from Dominguez-Pinos et al. 2005. 
communicating hydrocephalus. The loss of the ependyma of the dorsal wall of the SA occurring shortly after birth leads to fusion of the denuded ventral and dorsal walls of SA, resulting in aqueductal obliteration (Fig. 3E) and severe hydrocephalus (Fig. 3F) (Jiménez et al., 2001; Wagner et al., 2003; Páez et al., 2007). The phenomenon of VZ denudation associated with the onset of hydrocephalus has also been found in several mutant mice (Klezovitch et al., 2004; Imai et al., 2006; Ma et al., 2007; Rasin et al., 2007; Nechiporuk et al., 2007). Moreover, in human hydrocephalic fetuses, VZ/ ependymal denudation precedes, and probably triggers the onset of hydrocephalus (Domínguez-Pinos et al., 2005; Sival et al., 2011). It can be postulated, on solid grounds, that a primary alteration of the $\mathrm{VZ}$ due to various genetic defects triggers the onset of congenital hydrocephalus (Fig. 3). The loss of the VZ may trigger hydrocephalus through two different mechanisms. First, the abnormal expression of connexin 43 and the loss of the ependyma in the SA imply the abnormal function or the absence of multiciliated cells; consequently the flow of CSF through the aqueduct would be curtailed. Later, the complete loss of ependyma (perinatal period) leads to fusion of the denuded neuropiles and stenosis/obliteration of the SA. Collectively, these alterations cause severe hydrocephalus (Fig. 3A, E, F).

\section{DISRUPTION OF THE VENTRICULAR ZONE OF THE TELEN-} CEPHALON LEADS TO ABNORMAL NEUROGENESIS

In hyh mutant mice, the disruption of the $\mathrm{VZ}$ follows a program that has temporal and spatial patterns. The program is turned on at E12 (Fig. 1A) and turned off by the end of the second postnatal week. After the third postnatal week, and throughout the life span, the denuded areas remain devoid of ependyma (Fig. 3F). Spatially, the loss of the VZ progresses as a "tsunami" wave running from caudal to rostral regions of the developing ventricular system, leaving behind a severe damage (Fig. 1C, E, 3D) (Jiménez et al., 2001; Wagner et al., 2003; Páez et al., 2007). Disruption of the VZ after birth implies the loss of ependyma; however, the disruption of the $\mathrm{VZ}$ during fetal life results in the loss of NSCs (Fig. 1D, E) and a disorganization of the SVZ, indicating that abnormal neurogenesis and hydrocephalus are linked at the etiological level (Fig. 1B, 3A).

In the pathophysiologic program of $\mathrm{VZ}$ disruption, the loss of VZ/ependyma occurs in specific regions of the SA and ventricular walls, and at specific stages of brain development. This explains why only certain brain structures have an abnormal development, which in turn results in a specific neurological impairment (Jimenez et al., 2001; Wagner et al., 2003; Páez et al., 2007).

HOW AND TO WHAT EXTENT ARE THE PROLIFERATION, MIGRATION AND DIFFERENTIATION OF NEURAL PROGENITOR CELLS OF THE SVZ AFFECTED BY THE LOSS OF THE ADJACENT VZ?

Abnormal proliferation of neural progenitors. NPCs divide to generate either two proliferative daughter cells or one or two postmitotic neuronal daughter cells; the former predominates early, with neuron-generating divisions predominating later. In the SVZ of hyh mice, devoid of a VZ, there is an early overproduction of neurons at the expense of progenitor cells; this would explain the progressive loss of progenitor cells in hyh mutants from E12.5 on (Takahashi et al., 1994, 1995; Caviness and Takahashi, 1995; Caviness et al., 1995; Chae et al., 2004). The loss of the radial glia/neural stem cells forming the $\mathrm{VZ}$ is also expected to contribute to a reduced number of SVZ progenitors. There is apparently no information on the proliferative activity of SVZ neural precursors of human fetuses with disruption of the VZ.

Abnormal migration of neuroblasts. In human hydrocephalic fetuses, an abnormal expression of $\mathrm{N}$-cadherin, as seen in SA, has also been found in the VZ/ependyma of the telencephalon (Guerra et al., 2010). Many of these cases displayed extensive areas of the lateral ventricles with a disruption of the VZ/ ependyma and displacement of NPCs into the ventricle (Fig. 2I-L) (Domínguez-Pinos et al., 2005; de Wit et al., 2008; Guerra et al., 2010).

Impairment of neuronal migration gives rise to several genetic malformations of the developing cortex: lissencephaly (smooth brain), subcortical band heterotopia (heterotopic neurons arrested under the normal cerebral cortex) and periventricular heterotopia (PH) (Barkovich et al.,1991; Ricci et al., 1992; Kamuro and Tenokuchi 1993; Dobyns et al., 1996; Ferland et al., 2009). PHs are clusters of neuroblast/neurons ectopically positioned along the lateral ventricles (Fig. 3C) (Ferland et al., 2009). Humans with disruption in the VZ of the telencephalon carry $\mathrm{PH}$ primarily composed of later-born neurons (Ferland et al., 2009). Mutations in either of two human genes, filamin A (FLNA) or ADPribosylation factor guanine exchange factor 2 (ARFGEF2), cause PH (Sheen et al., 2001, 2003). In the mouse, the loss of FlnA function affects cell adhesion, disrupts the $\mathrm{VZ}$ and impairs neuronal migration. In the hyh mouse (carrying a mutation in $\alpha S n a p)$, the progressive denudation of the $\mathrm{VZ}$ also leads to $\mathrm{PH}$ formation (Chae et al., 2004; Ferland et al., 2009). These findings have led to the proposal that $\mathrm{PH}$ formation arises from a disruption in the VZ resulting from alterations of vesicle trafficking and cellcell adhesion (Ferland et al., 2009). Furthermore, disruption of the VZ implies the loss of radial glia. Therefore, neuronal migration would be expected to be impaired at the sites of VZ disruption, leading to the formation of PH (Fig. 3C) (de Wit et al., 2008; Ferland et al., 2009). Nevertheless, little is known about how much the disruption of the VZ in human fetuses affects corticogenesis. This key issue is under current investigation in our laboratories.

Abnormal neuron differentiation. In the hyh mutant, the brain cortex is markedly smaller as compared with wildtype embryos (Chae et al., 2004; Páez et al., 2007) and it has excessive early-born neurons (thicker layer VI) and few lateborn neurons (thinner layers II-IV). However, alteration of the cortex is not a widespread phenomenon. The loss of the $\mathrm{VZ}$ in specific regions of the ventricular walls and at specific stages of brain development explains why only certain brain structures have an abnormal development. Thus, in hyh mice and other animal models, the brain cortex is not affected homogeneously, with the cingular and frontal cortices being the most altered regions (Jones et al., 1987, 1991; Bruni et al., 1988; Páez et al., 2007).

How does disruption of the VZ affect the two main populations of cortical neurons, gabaergic and glutamatergic, considering that they arise from $\mathrm{VZ}$ located at different anatomical sites? In the mouse, most gabaergic neurons 

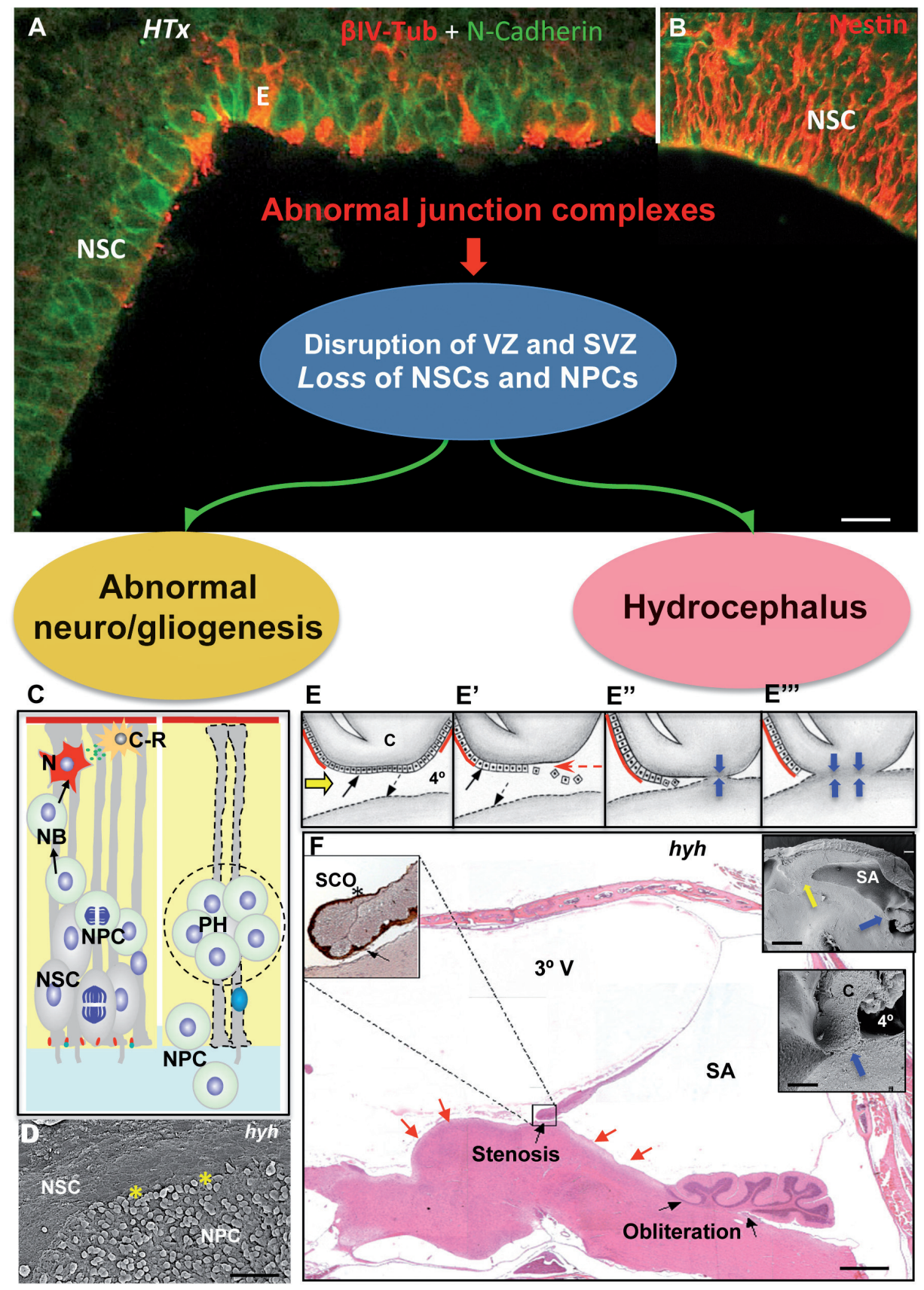

Figure 3. Abnormal junction complexes of cells forming the ventricular zone may lead to disruption of the ventricular and subventricular zones, hydrocephalus and abnormal neurogenesis. A, The lateral ventricle of PN1 HTx rats is lined by numerous neural stem cells (NSC, green) and a few ependymal cells (E, red), both cell types expressing N-cadherin. B, Area similar to that in Fig. A. Immunostaining for nestin shows that most cells of the ventricular zone are neural stem cells (NSC). C, Line drawing depicting the normal neurogenic process, from neural stem cells (NSC) to neural precursor cells (NPC), to migratory neuroblasts (NB) and finally to neurons (N). The loss of NSCs (right side of drawing) would lead to arrested migration of neuroblasts, thereby forming paraventricular heterotopias (PH) and translocation of NPCs into the ventricle. C-R, Cajal Retzius cell. D, In the hyh mouse, disruption of the ventricular zone (NSC, asterisks) exposes the NPCs of the subventricular zone to the ventricular cerebrospinal fluid. E-E'", In hyh mice, disruption of the VZ lining the ventral wall of the aqueduct occurs during early fetal life $\left(E\right.$, broken line). Disruption of the dorsal wall of aqueduct occurs shortly after birth ( $E^{\prime \prime}$, red arrow). Then the ventral and dorsal denuded walls fuse, leading to aqueduct obliteration ( $\mathrm{E}^{\prime \prime}, \mathrm{E}^{\prime \prime \prime}$, blue arrows) and hydrocephalus. F, Sagittal section of the brain of a hyh mouse with severe hydrocephalus. A marked stenosis of the rostral end of the aqueduct at the site of the subcommissural organ interferes with CSF circulation between the third ventricle $\left(3^{\circ} \mathrm{V}\right)$ and the Sylvian aqueduct (SA) and the obliteration of the caudal end of the SA blocks CSF circulation towards the fourth ventricle. Red arrows, denuded ventral walls. Top left inset, Detail of the stenosed region of SA. SCO, subcommisural organ. Right top inset, Scanning electron microscopy of a PN2 hydrocephalic hyh mouse, showing the zones of stenosis (yellow arrow), obliteration (blue arrow) and the expansion of the SA. Right bottom inset, Detail of obliterated region of SA (Blue arrow), C, cerebellum; 30, fourth ventricle. Bars: A, $25 \mu \mathrm{m} ; \mathrm{D}, 20 \mu \mathrm{m}$; F, $250 \mu \mathrm{m}$; right top inset, $400 \mu \mathrm{m}$; right bottom inset, $100 \mu \mathrm{m}$.

Fig. E: from Wagner et al. 2003. F: from Batiz et al. 2006. 
originate from the ganglionic eminences (Anderson et al., 1997, 2002; Corbin et al., 2001; Marín and Rubenstein, 2001, 2003; Wichterle et al., 2001; Nadarajah and Parnavelas, 2002). In hyh mice, the disruption of the $\mathrm{VZ}$ of the ganglionic eminences occurs from E14 on (Jiménez et al., 2001; Ferland et al., 2009), thus severely impairing neurogenesis of gabaergic neurons (Vío et al., 2010). By contrast, disruption of the VZ of the pallium occurs during the late period of development. Here, late glutamatergic neurons and gliogenesis would be expected to be impaired.

There is virtually no information on brain cortex alterations of human cases with disruption of the telencephalic VZ. One study reported a widespread loss and disorganization of the $\mathrm{VZ}$ in the brain of children with lissencephaly and other disorders of neuroblast migration (Sarnat et al., 1993).

AT SITES OF VZ DISRUPTION, NEURAL PROGENITORS OF THE SVZ ARE ABNORMALLY DISPLACED INTO THE VENTRICLE. WHAT IS THEIR FATE?

All mutant mice carrying a disruption of the VZ show neural progenitors reaching the ventricle. A puzzling question is the fate of neural progenitors reaching the ventricle. Do they undergo cell death? Do they get free in the CSF and move to distant locations? Do they continue proliferating in the CSF? The presence of apparently healthy NPCs on the denuded ventricular surface of hydrocephalic human fetuses (Fig. 2K, L) (Domínguez-Pinos et al., 2005) and their collection from the CSF of hydrocephalic fetuses (Krueger et al., 2006) support the possibility that in these human and animal mutant fetuses undergoing VZ disruption, those NPCs migrating through the denuded ventricular surface finally get free in CSF. The interesting question of the fate of the NSCs and NPCs reaching the CSF is fully open. Ongoing experiments in our laboratory indicate that these cells can be collected from the CSF and, under specific culture conditions, develop into neurospheres.

\section{ALTERATIONS OF THE MICROENVIRONMENT OF THE NEU- ROGENIC NICHE AFTER DISRUPTION OF THE VZ}

The microenvironment of the VZ and SVZ regulates the behavior of neuronal progenitors through diffusible signals (Kazanis et al., 2008). Many such signals have been found in fetal CSF (fCSF), indicating that fCSF is part of the neurogenic niche (Owen-Lynch et al., 2003; Gato et al., 2005; Miyan et al., 2006; Johanson et al., 2008, 2011; Gato and Desmond, 2009). Two proteomic analyses of fetal CSF of rats and humans have revealed numerous compounds that likely are cues for different phases of neurogenesis (Parada et al., 2005; Zappaterra et al., 2007). Although the origin of most of these fCSF compounds is unknown, some are secreted by specialized regions of the VZ such as the choroid plexus (Zappaterra et al., 2007; Johanson et al., 2008) and subcommissural organ (Rodríguez et al., 1998; Montecinos et al., 2005, Vío et al., 2007). Considering fCSF as part of the microenvironment of the VZ and SVZ, an abnormal hydrocephalic fCSF would be expected to affect the VZ and SVZ. Indeed, in vivo and in vitro studies of HTx rats that develop inherited hydrocephalus revealed that changes in fCSF composition may lead to abnormal corticogenesis (Mashayekhi et al., 2002).
IS THERE AN OPPORTUNITY FOR DIMINISHING/REPAIRING THE DISRUPTION OF THE VZ AND SVZ AND ITS CONSEQUENCES: ONSET OF HYDROCEPHALUS AND ABNORMAL NEUROGENESIS?

A distinction must be made between (i) brain maldevelopment due a primary pathology of the VZ that precedes or accompanies the onset of hydrocephalus, and (ii) neurological impairment due to brain damage caused by hydrocephalus. The former occurs during development and consequently hydrocephalic neonates are born with a neurological deficit. Brain damage is a postnatal acquired defect essentially caused by ventricular hypertension and abnormal CSF.

Brain damage is associated with regional ischemia, disruption of white matter pathways and alteration of the microenvironment of neural cells (Del Biggio, 2001, 2010). Derivative surgery, the almost exclusive treatment of hydrocephalus today, is aimed to prevent or diminish brain damage. It is clear that hydrocephalic patients improve clinically after shunting or ventriculostomy. The improvement is due to reduced intracranial pressure, which likely increases white matter blood flow (Del Bigio., 2001), and probably to resumption of the clearance role of CSF. However, derivative surgery does not reverse the inborn brain defects. This has led a study group on hydrocephalus to conclude that "Fifty years after the introduction of shunts for the treatment of this previously untreatable disorder, we must acknowledge that the shunt is not a cure for hydrocephalus; it is only a patch" (Bergsneider et al., 2006). One of the conclusions of the National Institutes of Health-sponsored workshop on "Priorities for hydrocephalus research" held in 2007 was: "The most forward-looking research priorities are for future treatments. These include not only the development of novel medical devices or surgical techniques, which represent a continuation of the first 50 years of hydrocephalus therapeutic research, but also the development of novel therapies that should emerge from improved understanding of the basic biology of hydrocephalus and its impact on the brain... There is a need to determine the potential role of stem cell therapy, for example, to supply trophic agents" (Williams et al., 2007).

Based on the evidence that the common history of fetal onset hydrocephalus and abnormal neurogenesis begins with disruption of the $\mathrm{VZ}$ and $\mathrm{SVZ}$, we have begun to explore strategies for diminishing/repairing such disruptions.

Grafting of stem cells or neurospheres into the CSF. There is growing evidence that NSC transplantation represents a great opportunity for the treatment of many neurological diseases (Sievertzon et al., 2005; Buddensiek et al., 2010, Gage, 2000; Armstrong and Svendson, 2000; Weissman, 2000; Neuhuber et al., 2008). Stem cells used for transplantation into the CNS include mesenchymal stem cells (hMSCs) (Satake et al., 2004), NSCs (Bai et al., 2003; Buddensiek et al., 2010) and NPCs (Kim et al., 2004; Ohta et al., 2004, Wu et al., 2002). NSCs can be obtained from fetal brain (Gage, 2000) and from regions of the adult brain such as the hippocampal subgranular zone/ dentate gyrus and the subventricular zone (Rietze et al., 2001). Under certain culture medium conditions, NSCs grow to form "neurospheres" (Park et al., 2008). Neurospheres are able to generate neurons, astroglia and oligodendroglia (Fig. 4A-J).

Worth noticing is that fetal and adult CSF is an important component of the microenvironment of NSCs and NPCs during 

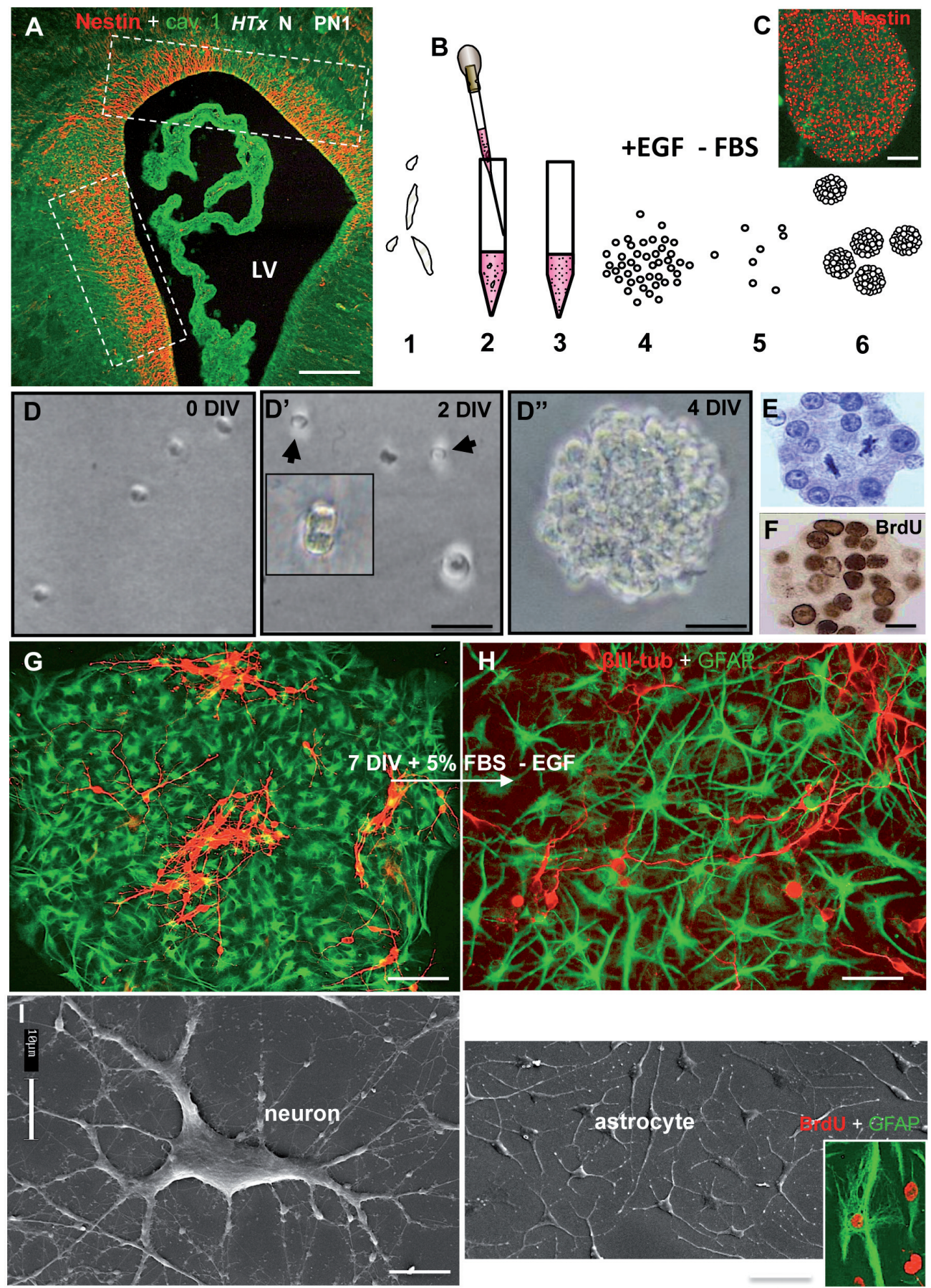

Figure 4. A single neural stem cell forms a neurosphere that after a few days in vitro can differentiate into neurons and glia. A, Brain of a HTx rat, at PN1, processed for double immunofluorescence to reveal nestin (red) and caveolin 1 (green). At this age, the dorsal and lateral walls of the lateral ventricles (LV) are lined by neural stem cells (red). These areas can be dissected out and used for NSC cloning. B, The neurosphere assay is a classical neural stem cell culture technique. After an initial dissection of the lateral ventricular wall (step 1), the tissue is transferred to a plastic falcon tube and mechanically disaggregated to obtain a single cell suspension (steps 2,3 ). The cells are then cultured in serum-free media in the presence of EGF as a mitogen (step 4). In the course of the first two days in vitro (DIV), the vast majority of differentiated cells die (step 5). The surviving ones undergo cell division and form spherical clones called "neurospheres" (3-4 DIV, step 6). D, D', D", Phase-contrast micrographs of NSC developing into neurospheres after 4 DIV. Inset: dividing NSC. E, A neurosphere fixed, embedded in paraffin, sectioned and stained with toluidine blue. Cells undergoing mitosis are seen. $\mathbf{F}$, A neurosphere cultured in the presence of BrdU, showing that all its cells are proliferative. G, A neurosphere cultured in a medium containing $5 \%$ fetal bovine serum (FBS) and devoid of EGF starts to differentiate into neurons ( $\beta$ III-tubulin, red) and astrocytes (GFAP, green). H, After a few days in vitro in this medium most cells have differentiated into neurons (red) and astrocytes (green). I, J, Cells similar to those seen in Fig. $\mathrm{H}$, but viewed under scanning electron microscopy. Inset: Double immunofluorescence for BrdU and GFAP to show that the differentiated astrocytes originate from the proliferative cells of neurospheres. Bars: D, D', $55 \mu \mathrm{m} ; D^{\prime \prime}, 20 \mu \mathrm{m} ; \mathrm{E}-\mathrm{F}, 10 \mu \mathrm{m} ; \mathrm{G}, 100 \mu \mathrm{m} ; \mathrm{H}, 40$ $\mu \mathrm{m}$; I-J, $10 \mu \mathrm{m}$; 
pre- and post-natal neurogenesis (Johanson et al., 2008, 2011). Therefore, CSF is expected to be a beneficial medium for NSC survival. Indeed, NSCs cultured in a medium containing CSF show increased survival and proliferation as compared to standard culture media (Gato et al., 2005). Adult human leptomeningeal (intrathecal) CSF is also an appropriate environment for the in vitro survival and differentiation of adult human NSCs (Buddensiek et al., 2010). Successful NSCs transplantation into the ventricular or subarachnoidal CSF also supports the view that CSF is a beneficial environment for NSCs to survive, growth and migrate (see below).

Current investigations in our laboratories indicate that neurospheres developed from NSCs collected from the SVZ of normal rats (see Fig. 4), when cultured in the presence of CSF from normal or hydrocephalic HTx rats, differentiate into neurons and glia. It seems likely that NSCs obtained from normal HTx rats, when grafted into a lateral ventricle of hydrocephalic HTx rats, would generate normal neuronal and glial lineages. We have just started exploring this possibility using neurospheres transfected with green fluorescence protein. Our goal is to promote incorporation of the grafted NSCs into the disrupted VZ and SVZ, in order to improve brain functions compromised by hydrocephalus

Delivery of NSCS, NPC or MSCs into CSF. CSF transplantation or explantation of stem/progenitor cells is emerging as an alternative to intraparenchymal grafts of therapeutic cells near injured neural tissue. The multifocal nature of multiple sclerosis makes intraparenchymal cellular therapy difficult. However, a hopeful strategy is to use the CSF administration pathway, which has widespread flow capabilities. Mice with experimental autoimmune encephalomyelitis (EAE) were grafted with neurospheres placed into ventricular CSF; the NPCs entered into demyelinating areas, differentiated into mature brain cells and promoted multifocal remyelination and functional recovery (Pluchino et al., 2003). In mice with induced stroke, NPCs have been administered into the parenchyma near the infarcts and into a lateral ventricle; CSF administration was more efficient in distributing NPCs to the lesion area (Kim et al., 2004). Hippocampus-derived neurosphere cells, isolated from a transgenic rat expressing green fluorescent protein, were transplanted into the fourth ventricle or cisterna magna of rats with spinal cord injury. The injected cells followed the flow of subarachnoidal CSF and survived as clusters on the pial surface of the spinal cord. Notably, a large number of them migrated into the lesion site, integrated into the injured spinal cord and survived within the host spinal cord for as long as 8 months without any tumorigenic changes (Wu et al., 2002, 2004; Bai et al., 2003). NSCs transplanted into the 4th ventricle of animals with injured dorsal roots reached the lesion root and associated with axons in the same manner as Schwann cells (Ohta et al., 2004). These two experiments indicate that grafted NSCs differentiate in a site-dependent manner (see also Rosser et al., 2000). Another approach has been the delivery of NSCs by lumbar puncture to rats with spine injury; cells travelled through the CSF to the site of injury in the spinal cord, differentiated into nestin-positive, immature neurons or glial cells (Satake et al., 2004) and supported neuroprotection and partial recovery of function (Neuhuber et al., 2008).

Immune cells and immune molecules have been shown to support neurogenesis from NSCs and NPCs in the adult brain
(González-Pérez et al., 2010; Molina-Holgado and MolinaHolgado, 2010). On the other hand, NPCs transplanted into mice after spinal cord injury contributed to functional recovery mostly by inducing microglia/macrophages to express their repairing phenotype secreting factors such as BDNF and noggin (Ziv et al., 2006; Ziv and Schwartz 2008). The onset of disruption of the VZ is associated with the arrival of microglia/ macrophages. Thus, the possibility of a fascinating cross talk between NSCs undergoing disruption and immune cells is being explored, since it could become a therapeutic target.

\section{ACKNOWLEDGEMENTS}

The authors wish to acknowledge the valuable technical support of Mr. Genaro Alvial. This work was supported by Grants from Fondecyt (Chile) 1070241 and 1111018 to EMR; Hydrocephalus Association Established Investigator Award to Drs. Rodríguez, McAllister and Johanson $N^{\circ}$ 51002705; Grants PS09/0376 from Instituto de Salud Carlos III (Spain) and PCI2006-A/-0669 from Ministerio de Educación y Ciencia (Spain) to AJJ; Universidad Austral de Chile/DID S-2006-72 to KV.

\section{REFERENCES}

ANDERSON SA, EISENSTAT DD, SHI L, RUBENSTEIN JL (1997) Interneuron migration from basal forebrain to neocortex: dependence on Dlx genes. Science 278:474-6.

ANDERSON SA, KAZNOWSKI CE, HORN C, RUBENSTEIN JL, MCCONNELL SK (2002) Distinct origins of neocortical projection neurons and interneurons in vivo. Cereb Cortex 12:702-9.

ARMSTRONG RJ, SVENDSEN CN (2000) Neural stem cells: from cell biology to cell replacement. Cell Transplant 9:139-52.

BAI H, SUZUKI Y, NODA T, ET AL (2003) Dissemination and proliferation of neural stem cells on the spinal cord by injection into the fourth ventricle of the rat: a method for cell transplantation. J Neurosci Methods 124:181-7.

BANIZS B, PIKE MM, MILLICAN CL, FERGUSON WB, KOMLOSI P, SHEETZ J, BELL PD, SCHWIEBERT EM, YODER BK (2005) Dysfunctional cilia lead to altered ependyma and choroid plexus function, and result in the formation of hydrocephalus. Development 132:5329-5339.

BARKOVICH AJ, KOCH TK, CARROL CL (1991) The spectrum of lissencephaly: report of ten patients analyzed by magnetic resonance imaging. Ann Neurol 30:139-46.

BÁTIZ LF, PÁEZ P, JIMÉNEZ AJ, RODRÍGUEZ S, WAGNER C, PÉREZFIGARES JM, RODRÍGUEZ EM (2006) Heterogeneous expression of hydrocephalic phenotype in the hyh mice carrying a point mutation in alpha-SNAP. Neurobiol Dis 23:152-68.

BÁTIZ LF, DE BLAS GA, MICHAUT MA, RAMÍREZ AR, RODRÍGUEZ F, RATTO MH, OLIVER C, TOMES CN, RODRÍGUEZ EM, MAYORGA LS (2009) Sperm from hyh mice carrying a point mutation in alphaSNAP have a defect in acrosome reaction. PLoS ONE 4:e4963.

BERGSNEIDER M, EGNOR MR, JOHNSTON M, KRANZ D, MADSEN JR, MCALLISTER JP $2^{\text {ND }}$, STEWART C, WALKER ML, WILLIAMS MA (2006) What we don't (but should) know about hydrocephalus. J Neurosurg 104:157-9.

BONFANTI L, PERETTO P (2007) Radial glial origin of the adult neural stem cells in the subventricular zone. Prog Neurobiol 83:24-36.

BRAZEL CY, ROMANKO MJ, ROTHSTEIN RP, LEVISON SW (2003) Roles of the mammalian subventricular zone in brain development. Prog Neurobiol 69:49-69.

BRUNI JE, DEL BIGIO MR, CARDOSO ER, PERSAUD TV (1988) Neuropathology of congenital hydrocephalus in the SUMS/NP mouse. Acta Neurochir (Wien) 92:118-22.

BUDDENSIEK J, DRESSEL A, KOWALSKI M, RUNGE U, SCHROEDER H, HERMANN A, KIRSCH M, STORCH A, SABOLEK M (2010) Cerebrospinal fluid promotes survival and astroglial differentiation of adult human neural progenitor cells but inhibits proliferation and neuronal differentiation. BMC Neurosci 11:48. 
CAVINESS VS, JR., TAKAHASHI T (1995) Proliferative events in the cerebral ventricular zone. Brain Dev 17:159-63

CAVINESS VS, JR., TAKAHASHI T, NOWAKOWSKI RS (1995)Numbers, time and neocortical neuronogenesis: a general developmental and evolutionary model. Trends Neurosci 18:379-83.

CHAE TH, KIM S, MARZ KE, HANSON PI, WALSH CA (2004) The hyh mutation uncovers roles for alpha Snap in apical protein localization and control of neural cell fate. Nat Genet 36:264-270.

CHENN A, ZHANG YA, CHANG BT, MCCONNELL SK (1998) Intrinsic polarity of mammalian neuroepithelial cells. Mol Cell Neurosci 11:183193.

CORBIN JG, NERY S, FISHELL G (2001) Telencephalic cells take a tangent: non-radial migration in the mammalian forebrain. Nat Neurosci 4 Suppl:1177-82.

DBOUK HA, MROUE RM, EL-SABBAN ME, TALHOUK RS (2009) Connexins: a myriad of functions extending beyond assembly of gap junction channels. Cell Commun Signal 7:4.

DERANGEON M, BOZON V, DEFAMIE N, PEINEAU N, BOURMEYSTER N, SARROUILHE D, ARGIBAY JA, HERVE JC (2009) 5-HT4 and 5-HT2 receptors antagonistically influence gap junctional coupling between rat auricular myocytes. J Mol Cell Cardiol 48:220-229.

DE WIT OA, DEN DUNNEN WFA, SOLLIE KM, MUÑOZ RI, MEINERS LCO, BROUWER F, RODRÍGUEZ EM, SIVAL DA (2008) Pathogenesis of cerebral malformations in human fetuses with meningomyelocele. Cerebrospinal Fluid Res 5:4.

DEL BIGIO MR (2001) Pathophysiologic consequences of hydrocephalus. Neurosurg Clin N Am 12:639-49.

DEL BIGIO MR (2010) Neuropathology and structural changes in hydrocephalus. Dev Disabil Res Rev 16:16-22.

DOBYNS WB, ANDERMANN E, ANDERMANN F, ET AL (1996) X-linked malformations of neuronal migration. Neurology 47:331-9.

DOMÍNGUEZ-PINOS MD, PÁEZ P, JIMÉNEZ A, WEIL B, ARRAEZ MA, PÉREZ-FIGARES JM, RODRÍGUEZ EM (2005) Ependymal denudation and alterations of the subventricular zone occur in human fetuses with a moderate communicating hydrocephalus. J Neuropathol Exp Neurol 64:595-604.

FERLAND RJ, BÁTIZ LF, NEAL J, LIAN G, BUNDOCK E, LU J, HSIAO $\mathrm{Y}$, DIAMOND R, MEI D, BANHAM A, BROWN P, VANDERBURG C, JOSEPH J, HECHT J, FOLKERTH R, GUERRINI R, WALSH C, RODRÍGUEZ EM, SHEEN V (2009) Disruption of neural progenitors along the ventricular and subventricular zones in periventricular heterotopia. Hum Mol Genet 18:497-516.

FUJIMOTO K, NAGAFUCHI A, TSUKITA S, KURAOKA A, OHOKUMA A, SHIBATA Y (1997) Dynamics of connexins, E-cadherin and alphacatenin on cell membranes during gap junction formation. J Cell Sci 110(Pt 3):311-322.

GAGE FH (2000). Mammalian neural stem cells. Science 287:1433-8.

GANZLER-ODENTHAL SI, REDIES C (1998) Blocking N-cadherin function disrupts the epithelial structure of differentiating neural tissue in the embryonic chicken brain. J Neurosci 18:5415-5425.

GATO A, MORO JA, ALONSO MI, BUENO D, DE LA MANO A, MARTIN C (2005) Embryonic cerebrospinal fluid regulates neuroepithelial survival, proliferation, and neurogenesis in chick embryos. Anat Rec A Discov Mol Cell Evol Biol 284:475-84

GATO A, DESMOND ME (2009) Why the embryo still matters: CSF and the neuroepithelium as interdependent regulators of embryonic brain growth, morphogenesis and histiogenesis. Dev Biol 327:263-72.

GONZÁLEZ-PÉREZ O, QUIÑONES-HINOJOSA A, GARCÍA-VERDUGO JM (2010) Immunological control of adult neural stem cells. J Stem Cells 5(1):23-31.

GOODENOUGH DA, GOLIGER JA, PAUL DL (1996) Connexins, connexons, and intercellular communication. Annu Rev Biochem 65:475-502

GOTZ M, HUTTNER WB (2005) The cell biology of neurogenesis. Nat Rev Mol Cell Biol 6:777-88

GUERRA M, SIVAL D, JIMÉNEZ A, DOMÍNGUEZ-PINOS D, DEN DUNNEN W, BATIZ F, PÉREZ-FIGARES JM, RODRÍGUEZ EM (2010) Defects in cell-cell junctions lead to neuroepithelial/ependymal denudation in the telencephalon of human hydrocephalic foetuses. Cerebrospinal Fluid Research 2010, 7(Suppl 1):S56.

HATTA K, TAKAGI S, FUJISAWA H, TAKEICHI M (1987) Spatial and temporal expression pattern of $\mathrm{N}$-cadherin cell adhesion molecules correlated with morphogenetic processes of chicken embryos. Dev Biol 120:215-227.

IMAI F, HIRAI S, AKIMOTO K, KOYAMA H, MIYATA T, OGAWA M, NOGUCHI S, SASAOKA T, NODA T, SHIGEO O (2006) Inactivation of
aPKClambda results in the loss of adherens junctions in neuroepithelial cells without affecting neurogenesis in mouse neocortex. Development 133:1735-44.

IVANOV DB, PHILIPPOVA MP, TKACHUK VA (2001) Structure and functions of classical cadherins. Biochemistry (Mosc) 66:1174-1186.

JACOBSEN M (1991) Developmental neurobiology. New York: Plenum.

JIMÉNEZ AJ, TOMÉ M, PÁEZ P, WAGNER C, RODRÍGUEZ S, FERNÁNDEZ-LLEBREZ P, RODRÍGUEZ EM, PÉREZ-FIGARES JM (2001) A programmed ependymal denudation precedes congenital hydrocephalus in the hyh mutant mouse. J Neuropathol Exp Neurol 60:1105-19.

JOHANSON C, DUNCAN JA, KLINGE PM, BRINKER T, STOPA E, SILVERBERG D (2008) Multiplicity of cerebrospinal fluid functions: New challenges in health and disease. Cerebrospinal Fluid Research $5: 10$

JOHANSON C, STOPA E, BAIRD A, SHARMA H (2011) Traumatic brain injury and recovery mechanisms: peptide modulation of periventricular neurogenic regions by the choroid plexus-CSF nexus. J Neural Transm 118(1):115-33.

JONES HC, DACK S, ELLIS C (1987) Morphological aspects of the development of hydrocephalus in a mouse mutant (SUMS/NP). Acta Neuropathol 72:268-76.

JONES HC, BUCKNALL RM, HARRIS NG (1991) The cerebral cortex in congenital hydrocephalus in the H-Tx rat: a quantitative light microscopy study. Acta Neuropathol 82:217-24.

JONES HC, KLINGE PM (2008) Hydrocephalus, 17-20th September, Hannover Germany: a conference report. Cerebrospinal Fluid Res 5:19.

JONGEN WM, FITZGERALD DJ, ASAMOTO M, PICCOLI C, SLAGA TJ, GROS D, TAKEICHI M, YAMASAKI H (1991) Regulation of connexin 43-mediated gap junctional intercellular communication by $\mathrm{Ca} 2+$ in mouse epidermal cells is controlled by E-cadherin. J Cell Biol 114:545555.

KAMIGUCHI H, HLAVIN ML, LEMMON V (1998) Role of L1 in neural development: what the knockouts tell us. Mol Cell Neurosci 12:48-55

KAMURO K, TENOKUCHI Y (1993) Familial periventricular nodular heterotopia. Brain Dev 15:237-41.

KAZANIS I, LATHIA J, MOSS L, FFRENCH-CONSTANT C (2008) The neural stem cell microenvironment. StemBook [Internet]. Cambridge (MA): Harvard Stem Cell Institute

KAZANIS I (2009) The subependymal zone neurogenic niche: a beating heart in the centre of the brain: how plastic is adult neurogenesis? Opportunities for therapy and questions to be addressed. Brain 132:2909-21.

KIM DE, SCHELLINGERHOUT D, ISHII K, SHAH K, WEISSLEDER R (2004) Imaging of stem cell recruitment to ischemic infarcts in a murine model. Stroke 35:952-7.

KLEZOVITCH O, FERNANDEZ TE, TAPSCOTT SJ, VASIOUKHIN V (2004) Loss of cell polarity causes severe brain dysplasia in Lgl1 knockout mice. Genes Dev 18:559-71.

KRUEGER RC, WU H, ZANDIAN M, DANIELPOUR M, KABOS P, YU JS, SUN YE (2006) Neural progenitors populate the cerebrospinal fluid of preterm patients with hydrocephalus. J Pediatr 148(3): 337-340.

LAIRD DW (2006) Life cycle of connexins in health and disease. Biochem J 394(Pt 3):527-43

MA X, BAO J, ADELSTEIN RS (2007) Loss of cell adhesion causes hydrocephalus in nonmuscle myosin II-B-ablated and mutated mice. Mol Biol Cell 18:2305-12.

MALATESTA P, APPOLLONI I, CALZOLARI F (2008) Radial glia and neural stem cells. Cell Tissue Res 331:165-78.

MARÍN O, RUBENSTEIN JL (2001) A long, remarkable journey: tangential migration in the telencephalon. Nat Rev Neurosci 2:780-90.

MARÍN O, RUBENSTEIN JL (2003) Cell migration in the forebrain. Annu Rev Neurosci 26:441-83.

MASHAYEKHI F, DRAPER CE, BANNISTER CM, POURGHASEM M, OWEN-LYNCH PJ, MIYAN JA (2002) Deficient cortical development in the hydrocephalic Texas (H-Tx) rat: a role for CSF. Brain 125:1859-74.

MERKLE FT, ALVAREZ-BUYLLA A (2006) Neural stem cells in mammalian development. Curr Opin Cell Biol 18:704-9.

MEYER RA, LAIRD DW, REVEL JP, JOHNSON RG (1992) Inhibition of gap junction and adherens junction assembly by connexin and A-CAM antibodies. J Cell Biol 119:179-189.

MIYAN J, SOBKOWIAK C, DRAPER C (2001) Humanity lost: the cost of cortical maldevelopment. Is there light ahead? Eur J Pediatr Surg 11 Suppl 1:S4-9. 
MIYAN JA, ZENDAH M, MASHAYEKHI F, OWEN-LYNCH PJ (2006) Cerebrospinal fluid supports viability and proliferation of cortical cells in vitro, mirroring in vivo development. Cerebrospinal Fluid Res 3:2.

MOLINA-HOLGADO E, MOLINA-HOLGADO F (2010) Mending the broken brain: neuroimmune interactions in neurogenesis. J Neurochem 114(5):1277-90.

MONTECINOS HA, RICHTER H, CAPRILE T, RODRIGUEZ EM (2005) Synthesis of transthyretin by the ependymal cells of the subcommissural organ. Cell Tissue Res 320:487-99.

MORI T, BUFFO A, GOTZ M (2005) The novel roles of glial cells revisited: the contribution of radial glia and astrocytes to neurogenesis. Curr Top Dev Biol 69:67-99.

NADARAJAH B, PARNAVELAS JG (2002) Modes of neuronal migration in the developing cerebral cortex. Nat Rev Neurosci 3:423-32.

NECHIPORUK T, FERNÁNDEZ TE, VASIOUKHIN V (2007) Failure of epithelial tube maintenance causes hydrocephalus and renal cysts in Dlg5-/- mice. Dev Cell 13:338-50.

NEUHUBER B, BARSHINGER AL, PAUL C, SHUMSKY JS, MITSUI T, FISCHER I (2008) Stem cell delivery by lumbar puncture as a therapeutic alternative to direct injection into injured spinal cord. J Neurosurg Spine 9:390-9.

OHTA M, SUZUKI Y, NODA T, KATAOKA K, CHOU H, ISHIKAWA N, KITADA M, MATSUMOTO N, DEZAWA M, SUZUKI S, IDE C (2004) Implantation of neural stem cells via cerebrospinal fluid into the injured root. Neuroreport 15:1249-53.

OKA C, MATSUDA H, SARAI N, NOMA A (2006) Modeling the calcium gate of cardiac gap junction channel. J Physiol Sci 56:79-85.

ORELLANA JA, SÁEZ PJ, SHOJI KF, SCHALPER KA, PALACIOSPRADO N, VELARDE V, GIAUME C, BENNETT MV, SÁEZ JC (2009) Modulation of brain hemichannels and gap junction channels by proinflammatory agents and their possible role in neurodegeneration. Antioxid Redox Signal 11(2):369-99.

OWEN-LYNCH PJ, DRAPER CE, MASHAYEKHI F, BANNISTER CM, MIYAN JA (2003) Defective cell cycle control underlies abnormal cortical development in the hydrocephalic Texas rat. Brain 126:623-31.

PÁEZ P, BÁTIZ LF, ROALES-BUJAN R, RODRÍGUEZ-PÉREZ LM, RODRÍGUEZ S, JIMÉNEZ AJ, RODRÍGUEZ EM, PÉREZ-FIGARES JM (2007) Patterned neuropathologic events occurring in hyh congenital hydrocephalic mutant mice. J Neuropathol Exp Neurol 66:1082-92.

PARADA C, GATO A, BUENO D (2005) Mammalian embryonic cerebrospinal fluid proteome has greater apolipoprotein and enzyme pattern complexity than the avian proteome. J Proteome Res 4:2420-8.

PARK IH, ARORA N, HUO H, MAHERALI N, AHFELD T, SHIMAMURA A, LENSCH MW, COWAN C, HOCHEDLINGER K, DALEY GQ (2008) Disease-specific induced pluripotent stem cells. Cell 134:877-86.

PÉREZ VELÁZQUEZ JL, CARLEN PL (2000) Gap junctions, synchrony and seizures. Trends Neurosci 23:68-74.

PLUCHINO S, QUATTRINI A, BRAMBILLA E, GRITTI A, SALANI G, DINA G, GALLI R, DEL CARRO U, AMADIO S, BERGAMI A, FURLAN R, COMI G, VESCOVI AL, MARTINO G (2003) Injection of adult neurospheres induces recovery in a chronic model of multiple sclerosis. Nature 422:688-94.

RASIN MR, GAZULA VR, BREUNIG JJ, KWAN K, JOHNSON M, LIUCHEN S, LI H, YEH L, JAN Y, SAKIC P, ESTAN N (2007) Numb and Numbl are required for maintenance of cadherin-based adhesion and polarity of neural progenitors. Nat Neurosci 10:819-27.

RICCI S, CUSMAI R, FARIELLO G, FUSCO L, VIGEVANO F (1992) Double cortex. A neuronal migration anomaly as a possible cause of LennoxGastaut syndrome. Arch Neurol 49:61-4.

RIETZE RL, VALCANIS H, BROOKER GF, THOMAS T, VOSS AK, BARTLETT PF (2001) Purification of a pluripotent neural stem cell from the adult mouse brain. Nature 412:736-9.

RODRÍGUEZ EM, RODRÍGUEZ S, HEIN S (1998) The subcommissural organ. Microsc Res Tech 41:98-123.

ROSSER AE, TYERS P, DUNNETT SB (2000) The morphological development of neurons derived from EGF- and FGF-2-driven human CNS precursors depends on their site of integration in the neonatal rat brain. Eur J Neurosci 12:2405-13.

ROUACH N, AVIGNONE E, MÊME W, KOULAKOFF A, VENANCE L, BLOMSTRAND F, GIAUME C (2002) Gap junctions and connexin expression in the normal and pathological central nervous system. Biol Cell 94(7-8):457-75

SÁEZ JC, BERTHOUD VM, BRANES MC, MARTÍNEZ AD, BEYER EC (2003) Plasma membrane channels formed by connexins: their regulation and functions. Physiol Rev 83:1359-1400.
SÁEZ JC, RETAMAL MA, BASILIO D, BUKAUSKAS FF, BENNETT MV (2005) Connexin-based gap junction hemichannels: gating mechanisms. Biochim Biophys Acta 1711(2):215-24.

SARNAT HB (1992) Role of human fetal ependyma. Pediatr Neurol 8:163-78

SARNAT HB, DARWISH HZ, BARTH PG, TREVENEN CL, PINTO A KOTAGAL S, SHISHIKURA K, OSAWA M, KOROBKIN R (1993) Ependymal abnormalities in lissencephaly/pachygyria. J Neuropathol Exp Neurol 52:525-41.

SATAKE K, LOU J, LENKE LG (2004) Migration of mesenchymal stem cells through cerebrospinal fluid into injured spinal cord tissue. Spine (Phila Pa 1976) 29:1971-9.

SHEEN VL, DIXON PH, FOX JW, HONG SE, KINTON L, SISODIVA SM, DUNCAN JS, DUBEAU F, SCHEFFER IE, SCHACHTER SC, WILNER A, HENCHY R, CRINO P, KAMURO K, DIMARIO F, BERG M, KUZNIECKY R, COLE AJ, BROMFIELD E, BIBER M, SCHOMER D, WHELESS I, SILVER K, MOCHIDA GH, BERKOVIC SF, ANDERMANN F, ANDERMANN E, DOBYNS WB, WALSH CA (2001) Mutations in the $X$-linked filamin 1 gene cause periventricular nodular heterotopia in males as well as in females. Hum Mol Genet 10:1775-83.

SHEEN VL, GANESH VS, TOPCU M, SEBIRE G, BODELL A, HILL RS, GRANT PE, SHUGART YY, IMITOLA J, KHOURY SJ, GUERRINI R, WALSH CA (2004) Mutations in ARFGEF2 implicate vesicle trafficking in neural progenitor proliferation and migration in the human cerebral cortex. Nat Genet 36:69-76.

SIEVERTZON M, WIRTA V, MERCER A, MELETIS K, ERLANDSSON R, WIKSTRÖM L, FRISÉN J, LUNDEBERG J (2005) Transcriptome analysis in primary neural stem cells using a tag cDNA amplification method. BMC Neurosci 6:28.

SIVAL D, GUERRA M, DEN DUNNEN WFA, BÁTIZ LF, ALVIAL G, CASTAÑEYRA-PERDOMO A, RODRÍGUEZ EM (2011) Neuroependymal denudation is in progress in full-term human foetal spina bifida aperta. Brain Pathol 21:163-179.

TAKAHASHI T, NOWAKOWSKI RS, CAVINESS VS, JR (1994) Mode of cell proliferation in the developing mouse neocortex. Proc Natl Acad Sci USA 91:375-9.

TAKAHASHI T, NOWAKOWSKI RS, CAVINESS VS, JR (1995) Early ontogeny of the secondary proliferative population of the embryonic murine cerebral wall. J Neurosci 15:6058-68.

TULLIO AN, BRIDGMAN PC, TRESSER NJ, CHAN CC, CONTI MA, ADELSTEIN RS, HARA Y (2001) Structural abnormalities develop in the brain after ablation of the gene encoding nonmuscle myosin II-B heavy chain. J Comp Neurol 433:62-74.

VIO K, RODRÍGUEZ S, YULIS CR, OLIVER C, RODRÍGUEZ EM (2008) The subcommissural organ of the rat secretes Reissner's fiber glycoproteins and CSF-soluble proteins reaching the internal and external CSF compartments. Cerebrospinal Fluid Res 5:3.

VIO K, OJEDA A, YULIS R, RODRÍGUEZ EM (2010) The disruption of the ventricular (VZ) and subventricular (SVZ) zones of the ganglionic eminences in hydrocephalic hyh mice is associated to abnormalities in the cortical GABAergic neurons. Cerebrospinal Fluid Research 2010, 7 (Suppl 1):S57.

WAGNER C, BÁTIZ LF, RODRÍGUEZ S, JIMÉNEZ AJ, PÁEZ P, TOMÉ M, PÉREZ-FIGARES JM, RODRÍGUEZ EM (2003) Cellular mechanisms involved in the stenosis and obliteration of the cerebral aqueduct of hyh mutant mice developing congenital hydrocephalus. J Neuropathol Exp Neurol 62:1019-40.

WEI CJ, FRANCIS R, XU X, LO CW (2005) Connexin43 associated with an $\mathrm{N}$-cadherin-containing multiprotein complex is required for gap junction formation in NIH3T3 cells. J Biol Chem 280:19925-19936

WEISSMAN IL (2000) Stem cells: units of development, units of regeneration, and units in evolution. Cell 100:157-68.

WICHTERLE H, TURNBULL DH, NERY S, FISHELL G, ÁLVAREZ-BUYLLA A (2001) In utero fate mapping reveals distinct migratory pathways and fates of neurons born in the mammalian basal forebrain. Development 128:3759-71.

WILLIAMS MA, MCALLISTER JP, WALKER ML, KRANZ DA, BERGSNEIDER M, DEL BIGIO MR, FLEMING L, FRIM DM, GWINN K, KESTLE JR, LUCIANO MG, MADSEN JR, OSTER-GRANITE ML, SPINELLA G (2007) Priorities for hydrocephalus research: report from a National Institutes of Health-sponsored workshop. J Neurosurg 107:345-57.

WU S, SUZUKI Y, NODA T, ET AL (2002) Immunohistochemical and electron microscopic study of invasion and differentiation in spinal cord lesion of neural stem cells grafted through cerebrospinal fluid in rat. J Neurosci Res 69:940-5. 
YUNG YC, MUTOH T, LIN ME, NOGUCHI K, RIVERA RR, CHOI JW, KINGSBURY MA, CHUN J (2011) Lysophosphatidic acid signaling may initiate fetal hydrocephalus. Sci Transl Med 3(99):99ra87

ZAPPATERRA MD, LISGO SN, LINDSAY S, GYGI SP, WALSH CA, BALLIF BA (2007) A comparative proteomic analysis of human and rat embryonic cerebrospinal fluid. J Proteome Res 6:3537-48.
ZIV Y, RON N, BUTOVSKY O, LANDA G, SUDAI E, GREENBERG N, COHEN H, KIPNIS J, SCHWARTZ M (2006) Immune cells contribute to the maintenance of neurogenesis and spatial learning abilities in adulthood. Nat Neurosci 9:268-75.

ZIV Y, SCHWARTZ M (2008) Orchestrating brain-cell renewal: the role of immune cells in adult neurogenesis in health and disease. Trends Mol Med 14:471-8. 